DOI: $10.19195 / 2300-7729.37 .8$

\author{
KATARZYNA DOBIJA \\ ORCID: 0000-0001-5941-6463 \\ Biblioteka Wydziału Fizyki, Astronomii i Informatyki Stosowanej \\ Uniwersytetu Jagiellońskiego
}

\title{
Postrzeganie zawodu bibliotekarza: stereotypy oraz opinie użytkowników Biblioteki Wydziału Fizyki, Astronomii i Informatyki Stosowanej Uniwersytetu Jagiellońskiego
}

Przed rozpoczęciem rozważań dotyczących wpływu stereotypów na postrzeganie zawodu bibliotekarza należy najpierw zastanowić się, czym są stereotypy. Zagadnieniu temu przez lata przyglądali się polscy naukowcy. W książce Stereotypy - walka z wiatrakami? ${ }^{1}$ Anna Bujakowska oraz Joanna Szadura podejmują próbę analizy współczesnych stereotypów i ich znaczenia w życiu jednostek oraz grup. Temat ten był wielokrotnie poruszany przez profesora Jacka Wojciechowskiego. W artykułach Stereotyp określa świadomośc ${ }^{2}$ oraz $W$ imadle stereotypów ${ }^{3}$ bada on ich genezę, jak również występowanie stereotypów dotyczących bibliotek i bibliotekarzy w opiniach społecznych. Stereotypom w kontekście bibliotekarstwa przyglądali się również Beata Kowalska oraz Dawid Kotlarek w artykule Bibliotekarz a stereotypy ${ }^{4}$. Zagadnienie postrzegania bibliotek oraz bibliotekarzy przez szeroką publiczność biblioteczną podjęli Aneta Firlej-Buzon w artykule Jak wyglada bibliotekarka? ${ }^{5}$, Tomasz Kruszewski w badaniach Wizerunek bibliotekarzy w opiniach ich następców $w^{6}$ oraz Agnieszka Folga w pracy Wizerunek biblio-

1 Stereotypy - walka z wiatrakami?, red. A. Bujakowska, J. Szadura, Lublin 2011.

2 J. Wojciechowski, Stereotyp określa świadomość, „Przegląd Biblioteczny” 2006, nr 4, s. $429-444$.

3 J. Wojciechowski, W imadle stereotypów, „Bibliotekarz” 2004, nr 2, s. 3-6.

4 B. Kowalska, D. Kotlarek, Bibliotekarz a stereotypy, ,Biuletyn EBIB” 2006, nr 10, http:// www.ebib.pl/2006/80/a.php?kowalska kotlarek [dostęp: 3.03.2018].

5 A. Firlej-Buzon, Jak wyglada bibliotekarka?, „Poradnik Bibliotekarza” 2003, nr 9, s. 3-6.

6 T. Kruszewski, Wizerunek bibliotekarzy w opiniach ich następców, „Bibliotekarz” 2005, nr 10, s. $8-12$. 
tekarza w opinii studentów I roku Uniwersytetu Pedagogicznego w Krakowie?. Znaczenie słowa „stereotyp” wyjaśniają również różne wydawnictwa encyklopedyczne. Według Encyklopedii PWN jest to „uproszczony, schematyczny obraz osób, grup, stosunków społecznych ukształtowany na podstawie niepełnej lub fałszywej wiedzy, utrwalony jednak przez tradycję i trudny do zmiany" ${ }^{\prime 8}$.

\section{Stereotypy}

Termin „stereotyp” został po raz pierwszy użyty w 1922 roku przez dziennikarza Waltera Lippmanna w celu opisania skłonności ludzi do postrzegania osób lub przedmiotów jako podobnych na podstawie ich wspólnych cech. Od tego czasu prowadzone są bardzo szerokie badania z zakresu psychologii, socjologii, lingwistyki, politologii oraz historii dotyczące tego zagadnienia ${ }^{9}$. Jak widać, stereotypy interesują badaczy reprezentujących różne dyscypliny naukowe, również bibliotekoznawców.

Stereotypy funkcjonują w życiu publicznym w formie ,,idei potocznej”, są chętnie i często używanym sformułowaniem, przytaczanym i powtarzanym bez jakiejkolwiek próby uzasadnienia. Takie, najczęściej negatywne, przekonania nie zostają w żaden sposób przetworzone, podlegając zamrożeniu i trwaniu w swojej uproszczonej postaci. Stereotypy powstają jako reakcja na słowo, nie zaś na zdarzenia rzeczywiste. W znacznym stopniu utrudnia to ich weryfikację ${ }^{10}$. Głębokie zakorzenienie stereotypów w kulturze danej grupy sprawia, że ludzie nabywają je już w procesie dorastania. Fakt, że stereotypy generują się z przeświadczeń otoczenia, oznacza, iż nie tylko zastępują one, lecz również niejako wyprzedzają osobiste doświadczenia. O trwałości stereotypów przesądza ich doniosłość społeczna. Znaczny wpływ na kształtowanie stereotypów mają tradycja oraz relacje historyczne, przekazane i utrwalone głównie w toku edukacji szkolnej. Ponadto rozpowszechniają je media, umacniając opinie i sposób patrzenia na świat przekazywany z pokolenia na pokolenie ${ }^{11}$.

7 A. Folga, Wizerunek bibliotekarza w opinii studentów I roku Uniwersytetu Pedagogicznego w Krakowie, „Annales Universitatis Paedagogicae Cracoviensis. Studia ad Bibliothecarum Scientiam Pertinentia" 14, 2016, s. 153-164.

${ }^{8}$ Encyklopedia PWN, http://encyklopedia.pwn.pl/haslo/3979617/stereotyp.html [dostęp: 16.02.2018].

9 Od stereotypu do wykluczenia, red. A. Fidelus, Warszawa 2014.

10 J. Wojciechowski, Stereotyp określa świadomość..., s. 430.

11 C.N. Macrae, C. Stangor, M. Hewstone, Stereotypy i uprzedzenia: najnowsze ujęcie, Gdańsk 1999, s. 58. 


\section{Stereotypy biblioteczne}

Z obiegowych opinii generuje się potoczny obraz danego zawodu, a co za tym idzie: jego pozycja, autorytet, warunki funkcjonowania, atmosfera oraz nastawienie otoczenia ${ }^{12}$. Stereotypy dotyczące bibliotek i pracujących w nich osób są doskonale znane oraz często poruszane w literaturze fachowej. Równocześnie są trudne do uchwycenia, gdyż rozpowszechniają się drogą nieformalną. Mimo to znaczna część osób zawodowo związanych z bibliotekami zdaje sobie sprawę z występujących powszechnie wyobrażeń, niejednokrotnie odczuwając ich negatywne skutki. W tym kontekście korzystniejszy wydaje się stereotyp bibliotek, mimo iż jest tożsamy ze stereotypem postaci bibliotekarza ${ }^{13}$.

Biblioteka jest postrzegana jako miejsce związane $\mathrm{z}$ edukacją oraz zdobywaniem wiedzy, dla pewnej grupy odbiorców kojarzy się również z rozrywką. Część publiczności bibliotecznej uważa biblioteki za przestarzałe, rygorystyczne placówki, w których dostęp do książek jest utrudniony, a czytelnik jest odstraszany przez pilnujący porządku personel ${ }^{14}$. Bibliotekarze są najczęściej postrzegani jako osoby nieporadne życiowo, uważające zasoby biblioteczne za swoją własność, które niechętnie wpuszczają czytelników do bibliotek, ponieważ naruszają oni panujący tam ład. Część społeczeństwa korzystająca z bibliotek postrzega bibliotekarzy w bardziej pozytywnym świetle. Uważają oni, że pracownicy książnic są dobrze wykształconymi, znającymi zbiory swoich bibliotek specjalistami, przygotowanymi do tego, aby służyć pomocą czytelnikom ${ }^{15}$.

Istnieje pewien „klasyczny rdzeń” tych stereotypów, wynikający z braku wiedzy, jakie procesy zachodzą w bibliotece i co właściwie robią osoby tam zatrudnione. Polega on na sztywnym kojarzeniu tych instytucji wyłącznie z książkami, co bezpośrednio pociąga za sobą opinię o ich starodawności, zacofaniu i niedostosowaniu do nowoczesnego świata ${ }^{16}$. Według tego wyobrażenia praca bibliotekarza polega na wypożyczaniu książek, rzadziej na udzielaniu informacji, przede wszystkim zaś na swobodnym czytaniu w czasie wolnym, którego osoba ta ma szczególnie dużo. Wiedza o faktycznych kwalifikacjach oraz wewnętrznym podziale pracy bibliotecznej jest znikoma ${ }^{17}$. Zgodnie z tym punktem widzenia każdy pracownik biblioteki, który nie obsługuje czytelnika, wywołuje irytację i sprawia, iż wydaje się on zbędny. Istnieją składniki obiegowych stereotypów, które znajdują potwierdzenie w rzeczywistości, stąd też wynika ich wyjątkowa trwałość. Takie powszechne i prawdziwe jest przekonanie o feminizacji zawodu bibliotekarza, co — z niewiadomych przyczyn — obniża jego prestiż w stosunku

12 J. Wojciechowski, Stereotyp określa świadomość..., s. 429.

13 Ibidem, s. 433.

14 J. Wojciechowski, W imadle stereotypów..., s. 4.

15 J. Sobocha-Stanuch, P. Picheta, Stereotypy bibliotekarzy, http://www.profuturo.agh.edu.pl [dostęp: 15.07.2013].

16 Ibidem.

17 J. Kołodziejska, Polubić bibliotekarzy, „Notes Wydawniczy” 1996, nr 6, s. 36. 
do innych profesji ${ }^{18}$. Niekorzystne jest również przeświadczenie o wiekowym zaawansowaniu pracowników bibliotek. Obraz starszej pani uciszającej wszystkich wokół obecny jest zwłaszcza w świadomości młodych odbiorców - uczniów i studentów. To wpływa na przetrwanie tego stereotypu przez kolejne lata ${ }^{19}$. Wizerunek zewnętrzny bardzo łatwo może stać się podłożem stereotypów. Pierwsze wrażenie jest często podstawową determinantą dokonywanych ocen. Określony wygląd przyporządkowany jest do konkretnych cech charakteru. Zjawisko to nazwano w psychologii efektem pozornej korelacji. Wygląd zewnętrzny może być czynnikiem sprzyjającym budowaniu dobrej relacji z czytelnikiem. Prezentowany wizerunek stanowi formę komunikatu dla otoczenia. Informuje, kim bibliotekarz jest we własnym mniemaniu i jak chciałby być postrzegany przez społeczeństwo ${ }^{20}$.

\section{Badania wizerunku bibliotek i bibliotekarzy}

W ciągu ostatnich lat przeprowadzono na gruncie polskim kilka badań mających na celu uzyskanie informacji na temat odbioru bibliotekarzy przez szeroką publiczność. Najgłośniejsze z nich, autorstwa Anety Firlej-Buzon ${ }^{21}$, wywołało gorącą dyskusję w środowisku. Kontrowersje wzbudziła zwłaszcza część dotycząca wyglądu bibliotekarek. Zgodnie z wynikami ankiety przeciętny bibliotekarz to:

kobieta w średnim wieku, wysoka i szczupła. Ubrana w nieokreślonego koloru sweter oraz szaroburą spódnicę. Ma najczęściej zmęczoną, bladą twarz oraz smutne spojrzenie, nie stosuje makijażu i nie lubi biżuterii. Jedyny rzucający się w oczy element jej twarzy stanowią okulary z grubymi szkłami w niemodnej, dużej oprawce przysłaniającej rysy. Fryzura bibliotekarki jest staranna, ale włosy są zdecydowanie siwe. Jeżeli są dłuższe, wówczas przeważnie upina je w przysłowiowy kok. Ulubione obuwie bibliotekarek stanowią niezbyt modne buty koniecznie na płaskim obcasie ${ }^{22}$.

Zarysowany wyżej wizerunek jest bardzo popularnym stereotypem. Taki odbiór smuci tym bardziej, iż ankietowanymi byli przyszli absolwenci bibliotekoznawstwa. W badaniach Tomasza Kruszewskiego z 2005 Wizerunek bibliotekarzy w opiniach ich następców możemy znaleźć taki opis:

Co się zaś tyczy wyglądu bibliotekarza, to pierwsze skojarzenia były podobne u większości ankietowanych. Zbliżone były one do stereotypów: kobieta zadbana raczej w ograniczonym zakresie, tzn. bez makijażu, atrakcyjnej fryzury, w okularach, w nierzucającym się w oczy spokojnym i stonowanym ubraniu. Obraz eleganckiego, efektownego bibliotekarza/ki pojawiał się $\mathrm{w}$ ankietach sporadycznie ${ }^{23}$.

18 R.A. Kneale, You don't look like a librarian!, http://www.librarian-image.net/perc.html [dostęp: 16.02.2018].

19 J. Wojciechowski, Stereotyp określa świadomość..., s. 435.

${ }^{20}$ G. Kmita, Stereotyp bibliotekarza w spoteczeństwie a problem identyfikacji zawodowej bibliotekarzy, „Notes Biblioteczny” 2007, nr 2, s. 12-13.

21 A. Firlej-Buzon, op. cit., s. 3-6.

22 Ibidem, s. 3.

23 T. Kruszewski, op. cit., s. 10. 
Po dziesięciu latach badania zostały powtórzone w celu porównania, jak zmieniły się opinie studentów na temat tego zawodu. W dalszym ciągu wygląd bibliotekarza kojarzył się ankietowanym ze stereotypowym wyobrażeniem: „skromnie (lub staromodnie) ubrana kobieta w średnim wieku, w okularach". Należy jednak zwrócić uwagę na fakt, że po upływie dekady częściej przytaczany był „obraz osoby dobrze lub elegancko ubranej" 24 .

W 2016 roku została przeprowadzona ankieta Wizerunek bibliotekarza w opinii studentów I roku Uniwersytetu Pedagogicznego w Krakowie ${ }^{25}$. Kierowana była ona do studentów pierwszego roku i miała na celu zbadanie sposobu postrzegania osób pracujących w bibliotekach. Ankietowani określili bibliotekarzy jako osoby: cierpliwe, uprzejme, komunikatywne, kulturalne, inteligentne, profesjonalne cechy negatywne były zdecydowanie w mniejszości. Praca w bibliotece została opisana głównie jako nudna i bezstresowa. Bibliotekarzami zostają zazwyczaj osoby spokojne i sumienne. Najbardziej pożądane formy zachowania bibliotekarzy to: pomocny, oczytany, miły. Respondenci uznali, że bibliotekarzami zostają głównie kobiety (98\%), a 66\% ankietowanych nie chciałoby pracować w bibliotece. $\mathrm{Z}$ badań tych wynika również, że postawa pracowników biblioteki ma bardzo duży wpływ na jej wizerunek.

\section{Ankieta - analiza wyników}

W listopadzie 2017 roku wśród czytelników Biblioteki Wydziału Fizyki, Astronomii i Informatyki Stosowanej Uniwersytetu Jagiellońskiego przeprowadzone zostały badania ankietowe, których celem było ustalenie, jak użytkownicy Biblioteki postrzegają bibliotekarzy oraz czy sposób przedstawienia bibliotekarzy w literaturze ma wpływ na odbiór tej grupy zawodowej przez czytelników. Ankieta składała się z siedmiu pytań zamkniętych oraz czterech otwartych, wzięło w niej udział osiemdziesiąt jeden osób, z czego zdecydowana większość wypełniła ankietę $\mathrm{w}$ formie papierowej, mimo że dostępna była również wersja elektroniczna. Wiek osób został ustalony w przedziałach 18-20, 21-25, 26-30, 31-40 i powyżej 40 lat. Takie przypisanie wieku ankietowanych miało na celu ustalenie, jakie zdanie o bibliotekarzach mają czytelnicy na pierwszym roku studiów, jakie na kolejnych latach oraz czy postawy bibliotekarzy zatrudnionych w Bibliotece WFAIS UJ wpływają na postrzeganie tego zawodu przez użytkowników biblioteki. Najwięcej ankietowanych zaznaczyło przedział wiekowy 21-25 lat (47\%), następnie 18-20 (34\%), zdecydowanie mniej osób zaznaczyło pozostałe odpowiedzi 26-30 (9\%), 31-40 (5\%) oraz powyżej 40 lat (5\%). W badaniu wzięła udział porównywalna liczba kobiet (51\%) oraz mężczyzn (49\%).

24 T. Kruszewski, Wizerunek bibliotekarzy w opiniach ich następców po dekadzie - raport z badań, „Przegląd Biblioteczny” 84, 2016, z. 4, s. 548.

25 A. Folga, op. cit., s. 153-164. 
Pierwsze zagadnienie, o które zapytano respondentów, dotyczyło cech charakteru bibliotekarzy. Było to pytanie zamknięte, w którym ankietowani mogli wybrać cztery z szesnastu odpowiedzi. Bibliotekarze zostali ocenieni przez respondentów jako osoby pomocne (77,8\%), miłe oraz uprzejme (po 54,3\%), cierpliwe $(43,2 \%)$, profesjonaliści $(30,9 \%)$, dobrze wykształcone $(17,3 \%)$, uczciwe $(16 \%)$, pracowite $(13,6 \%)$, zajęte własnymi sprawami $(9,9 \%)$, nieśmiałe $(4,9 \%)$, złośliwe $(3,7 \%)$, wywyższające się $(2,5 \%)$ oraz aroganckie, przemądrzałe i nudne (po 1,2\%). Odpowiedzi ankietowanych wykazały, że nie ma zależności między wiekiem a postrzeganiem cech charakteru bibliotekarzy. Zarówno studenci pierwszego roku, jak i czytelnicy będący na kolejnych latach studiów wskazywali cechy pozytywne. Wśród respondentów w wieku 21-25 lat częściej wybierano odpowiedź „Zajęty własnymi sprawami”.

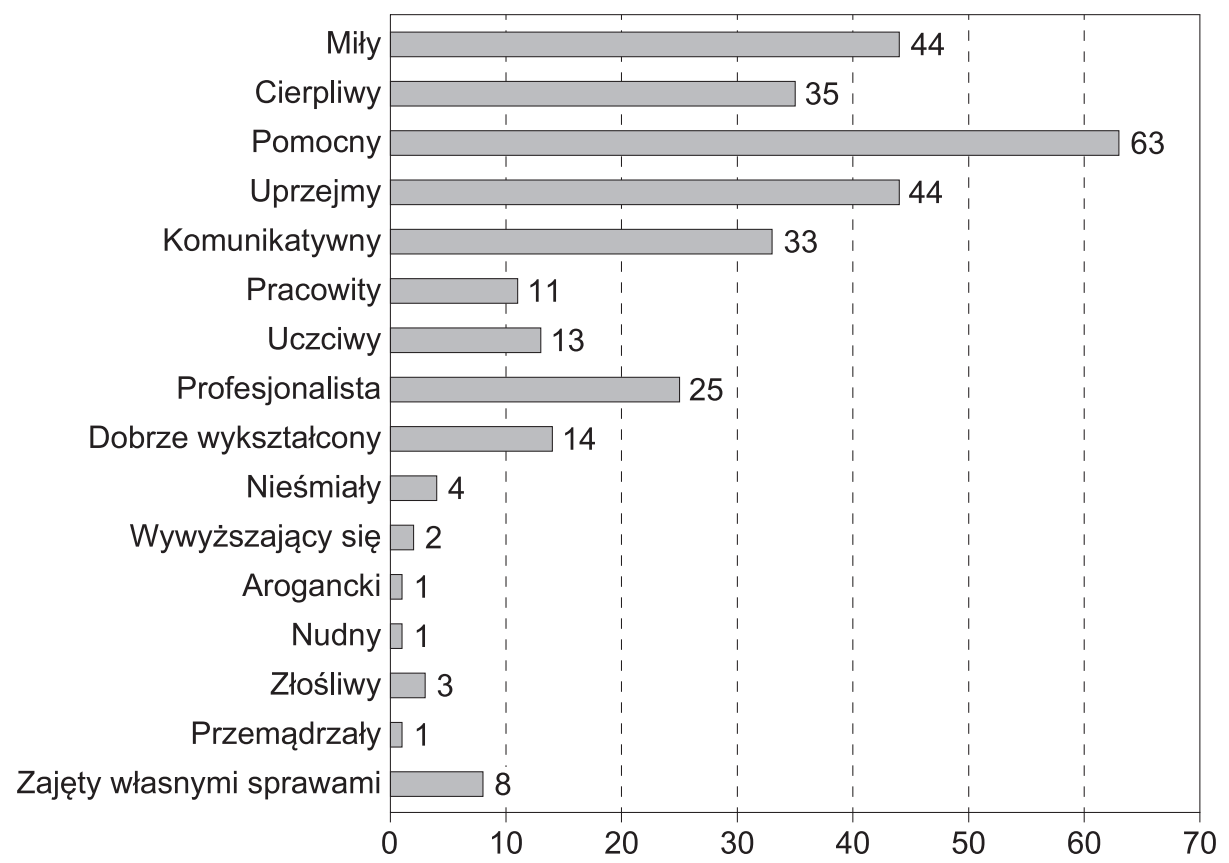

Wykres 1. Jakie cechy uważają Państwo za dominujące w przypadku bibliotekarzy?

Źródło: opracowanie własne, 15 lutego 2018.

Kolejne pytanie było również zamknięte, ankietowani mieli do wyboru cztery z jedenastu odpowiedzi, za pomocą których mogli wyrazić swoją opinię na temat pracy w bibliotece. Respondenci uznali pracę w bibliotece za spokojną $(70,4 \%)$, cichą $(50,6 \%)$, bezstresową $(50,6 \%)$, sformalizowaną $(27,2 \%)$, ciekawą $(25,9 \%)$, dającą satysfakcję (23,5\%), rozwijającą (17,3\%), nudną (11,1\%), przestarzałą $(7,4 \%)$, innowacyjną (4\%). Za nudną uznały ją osoby w wieku powyżej 20 lat. Pozostałe określenia pojawiały się bez względu na wiek. 


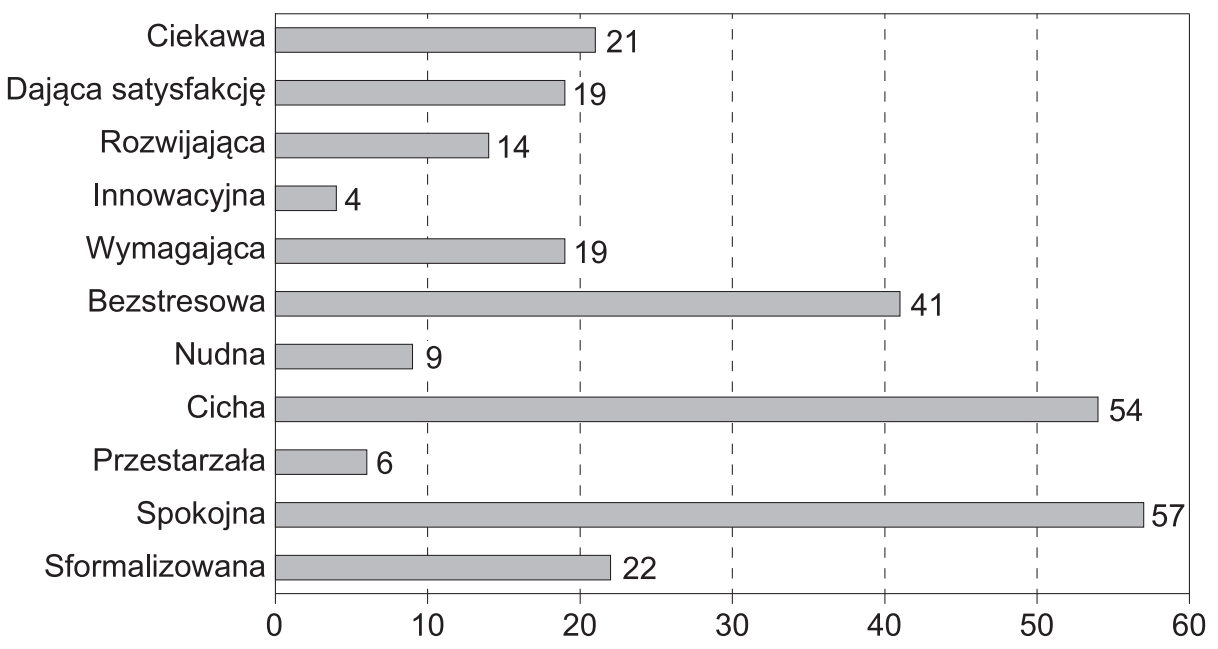

Wykres 2. Które z wymienionych określeń przypisaliby Państwo do pracy w bibliotece? Źródło: opracowanie własne, 15 lutego 2018.

Trzecie pytanie dotyczyło postrzegania bibliotek przez użytkowników. Ankietowani mieli za zadanie wybrać cztery z dziewięciu przygotowanych odpowiedzi. Biblioteki uważane są przez respondentów za miejsca ciche $(87,3 \%)$, pełne wiedzy $(77,2 \%)$, przytulne $(69,6 \%)$, nowoczesne $(39,2 \%)$, z formalną atmosferą $(27,8 \%)$, pełne zakazów $(8,9 \%)$, staroświeckie $(7,6 \%)$, nudne $(2,5 \%)$ i nieprzyjazne $(1,3 \%)$. Tym razem wiek ankietowanych nie miał znaczenia, zdarzały się jednak osoby, które zaznaczyły, że jest to miejsce zarówno nowoczesne, jak i staroświeckie. Ponadto jedna $\mathrm{z}$ ankiet zawierała dodatkową informację, że w bibliotece nie jest wystarczająco cicho.

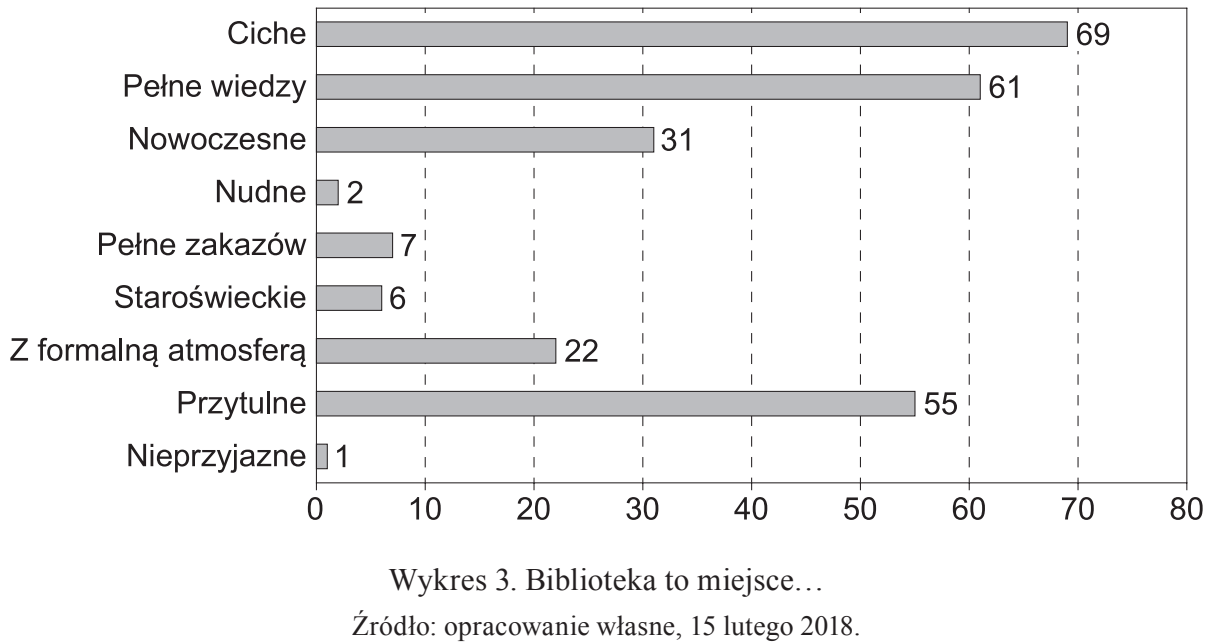


W następnym pytaniu, również zamkniętym, poproszono ankietowanych o wskazanie cech fizycznych bibliotekarza. Można było wybrać cztery z dziesięciu odpowiedzi. Respondenci uznali, że osobami pracującymi w bibliotece są zazwyczaj kobiety $(87,3 \%)$, są one uśmiechnięte $(59,5 \%)$, częściej jest to osoba starsza (41,8\%), dbająca o wygląd oraz nosząca okulary (po 34,2\%); rzadziej jest to osoba młodsza (25,3\%), atrakcyjna (12,7\%), niemodnie ubrana (11,4\%), zaniedbana (7,6\%); najmniej głosów zdobyła odpowiedź, że jest to mężczyzna (2,5\%). Odpowiedzi te potwierdzają przekonanie o feminizacji zawodu, jednakże użytkownicy bibliotek dostrzegają pozytywne zmiany w wyglądzie pracowników książnic docenione zostały uśmiech oraz dbanie pracowników o wygląd. W tym pytaniu wiek nie wpływał w wyraźny sposób na odpowiedzi ankietowanych.



Wykres 4. Które z wymienionych cech fizycznych najbardziej pasują do spotkanych przez Państwa bibliotekarzy?

Źródło: opracowanie własne, 15 lutego 2018.

Kolejne zagadnienie składało się z czterech części i dotyczyło bibliotekarzy oraz bibliotek pojawiających się na kartach utworów literackich. Pierwsze pytanie było pytaniem zamkniętym - ankietowani mogli wybrać jedną z dwóch odpowiedzi. Miało ono na celu ustalenie, czy czytelnicy w ogóle spotkali się z bibliotekarzem lub biblioteką w czytanej literaturze. Jeśli odpowiedzieli przecząco, to następne części tego pytania zostawały przez nich pominięte. Mniej więcej połowa ankietowanych odpowiedziała twierdząco na to pytanie (48\%), średnio ankietowani pamiętali około dwóch-trzech takich pozycji. Próbowano również ustalić, jaki był wyłaniający się z kart powieści wizerunek bibliotekarza lub biblioteki. Według ankietowanych zdecydowanie przeważało pozytywne przedstawienie zawodu $-47 \%$, negatywny oraz neutralny wizerunek zaobserwowało w czytanej literaturze po $25 \%$ ankietowanych. Ostatnią częścią tego zagadnienia było pytanie otwarte mające na celu poznanie zapamiętanych przez respondentów 
tytułów książek, żeby sprawdzić, jaki wizerunek bibliotekarzy wyłania się z kart tych pozycji i jak to może wpływać na odbiór bibliotekarzy oraz bibliotek przez czytelników, którzy nie mają z nimi kontaktu na co dzień. Ankietowani wskazali następujące tytuły:

- J.K. Rowling - cykl o Harrym Potterze,

- Stephen King — Skazani na Shawshank,

— książki Andrzeja Pilipiuka,

- Andrzej Sapkowski - Wiedźmin,

— Terry Pratchett — cyk1 „Świat Dysku”,

- Umberto Eco - Imię róży,

- Dan Brown - Kod Leonarda da Vinci, Anioty i demony,

- Haruki Murakami - Kafka nad morzem,

— Rafał Kosik - cykl „Felix, Net i Nika”,

- Vicki Myron, Bret Witter - Dewey: wielki kot w matym mieście,

- Carlos Ruiz Zafón - Cień wiatru.

W dziełach wymienionych przez respondentów pojawiają się zarówno biblioteki, jak i bibliotekarze, wizerunek oraz intensywność ich występowania w utworach są różne. Czasami są to tylko wzmianki lub chwilowe przeniesienie akcji do biblioteki, w części utworów akcja toczy się głównie w niej. Najczęściej pojawiającą się wśród ankietowanych odpowiedzią była seria autorstwa J.K. Rowling o przygodach młodego czarodzieja ${ }^{26}$. W książkach przedstawiono bibliotekę znajdującą się w Szkole Magii i Czarodziejstwa Hogwart i pracującą w niej bibliotekarkę. Wizja książnicy szkolnej jest niezwykle pozytywna — znajduje się w niej ciekawy księgozbiór, podzielony, tak jak w tradycyjnej bibliotece, na działy, który zawiera odpowiedzi na wszelkie zadawane przez młodych adeptów magii pytania, czasami tylko trzeba się trochę bardziej natrudzić, żeby je znaleźć. Ten sielankowy obrazek niszczy postać Irmy Pince, bibliotekarki, która odstrasza czytelników i stara się, jak może, by utrudnić im korzystanie z księgozbioru. Bibliotekarka przedstawiona została, w karykaturalny wręcz sposób, jako osoba wywyższająca się, niemiła oraz bardzo niechętna do pomocy czytelnikom.

Bardzo podobnie przestawiona została bibliotekarka pracująca w bibliotece szkolnej stworzonej na kartach powieści przez Rafała Kosika ${ }^{27}$. Bohaterowie cyklu „Felix, Net i Nika” bardzo często zaglądają do biblioteki szkolnej w poszukiwaniu informacji do rozwiązania kolejnej zagadki. Pracująca tam Michalina Małolepsza zna na pamięć cały księgozbiór, ale utrudnia czytelnikom dostęp do niego. Wszędzie węszy podstęp, a uczniów traktuje jak wrogów i zagrożenie dla bibliotecznego ładu. To bardzo negatywny obraz bibliotekarza przekazywany w książkach chętnie czytanych przez młodych czytelników, które, jak wynika z odpowiedzi ankietowanych, zostały przez większość z nich zapamiętane.

26 J.K. Rowling, Harry Potter i kamień filozoficzny, Warszawa 2000; eadem, Harry Potter i czara ognia, Warszawa 2001; eadem, Harry Potter i Zakon Feniksa, Warszawa 2004.

27 R. Kosik, Felix, Net i Nika oraz Gang Niewidzialnych Ludzi, Warszawa 2011. 
Wśród wymienionych autorów znalazły się jeszcze dwa polskie nazwiska. Andrzej Pilipiuk w swoim cyklu opowiadań o Robercie Stormie, detektywie poszukującym zaginionych w czasie wojny przedmiotów, bardzo często odsyła głównego bohatera do licznych warszawskich bibliotek ${ }^{28}$. Przedstawione one zostały jako miejsca z ogromną ilością informacji, do których dostęp jest jednak utrudniony, czy to przez brak przyjaznego dla użytkowników katalogu, czy też przez nieintuicyjny rozkład księgozbioru. Bibliotekarze prezentowani przez autora to zazwyczaj wykształceni specjaliści, którzy są w stanie odnaleźć poszukiwane materiały, jednak są oni zazwyczaj wyniośli i aroganccy.

Z kolei w cyklu Andrzeja Sapkowskiego o Wiedźminie ${ }^{29}$ biblioteka pojawia się rzadko i raczej jako miejsce miłosnych schadzek. Nie ma też opisanego na kartach powieści klasycznego bibliotekarza, jednakże w książce występuje postać prywatnego detektywa, który jest w stanie dowiedzieć się wszystkiego. Współpracuje on z karłem, który całymi dniami przesiaduje w prywatnej bibliotece, posiadającej księgozbiór gromadzony przez pokolenia. Z kart powieści wyłania się obraz ogromnej biblioteki, kryjącej w sobie niezgłębioną wiedzę, a osoba, która wie, jak z niej korzystać, może dzięki temu dużo zyskać, zarówno finansowo, jak i wizerunkowo. Postacie detektywa i karła otaczane są powszechnym szacunkiem oraz pewnego rodzaju tajemniczością. Jest to pozytywne przedstawienie biblioteki i osób, które potrafią korzystać ze znajdującej się w niej wiedzy.

Wśród anglojęzycznych pisarzy znany wszystkim mistrz grozy i horrorów Stephen King w jednym ze swoich opowiadań opisuje więzienie Shawshank i pracujących tam bibliotekarzy ${ }^{30}$. Oczywiście chodzi o zekranizowane w 1994 roku opowiadanie Skazani na Shawshank. W więziennej bibliotece pracował przez lata Brooks - starszy mężczyzna, który prawie całe swoje życie spędził w odosobnieniu, jego głównym obowiązkiem, jako bibliotekarza, był cowieczorny obchód cel i proponowanie współwięźniom książek. Sama biblioteka była niewielka i miała bardzo ubogi księgozbiór. Po zwolnieniu warunkowym Brooksa rolę więziennego bibliotekarza przejął Andy, który postanowił zmienić małą bibliotekę w największą i najnowocześniejszą bibliotekę więzienną. W tym celu zwracał się o pomoc do różnych instytucji rządowych oraz innych bibliotek z prośbą o przekazanie funduszy lub książek im już niepotrzebnych. Ostatecznie dzięki swojemu uporowi osiągnął cel - jego biblioteka miała nawet płyty winylowe i gramofon, na którym można było ich słuchać.

Innym często pojawiającym się wśród odpowiedzi ankietowanych autorem, który w swoich książkach przedstawia bibliotekę oraz jej pracownika, jest Terry Pratchett $^{31}$. W cyklu „Świat Dysku” opisana została biblioteka uniwersytecka,

28 A. Pilipiuk, Wilcze leże, Lublin 2017.

29 A. Sapkowski, Czas pogardy, Warszawa 2011.

30 S. King, Cztery pory roku, Warszawa 2015.

31 T. Pratchett, Straż! Straż!, Warszawa 2005; idem, Wiedźmikołaj, Warszawa 2004; idem, Zbrojni, Warszawa 2005; idem, Niewidoczni akademicy, Warszawa 2010. 
znajdująca się na Niewidzialnym Uniwersytecie. Biblioteka ta jest magiczna, jednakże w przeciwieństwie do biblioteki w Hogwarcie budzi lęk wśród użytkowników. Na ciągnących się bez końca regałach znajdują się książki, które w każdej chwili mogą zaatakować czytelnika, dodatkowo bardzo łatwo można się w niej zgubić i nigdy nie wiadomo, kiedy i gdzie się ostatecznie trafi. Na straży zbiorów bibliotecznych stoi bibliotekarz, zamieniony przez przypadek przed laty w orangutana. Nie przeszkadza mu to jednak w czerpaniu radości ze swojej pracy. Bibliotekarz dba, jak może, o swoje zbiory, stara się na bieżąco je naprawiać oraz bronić ich przed czytelnikami. Choć bohater opisany w „Świecie Dysku” posiada wiele cech stereotypowych, a jego podejście do czytelników pozostawia wiele do życzenia, mimo wszystko jest postacią pozytywną. Terry Pratchett stworzył bibliotekarza oddanego swojej pracy, zaangażowanego w działalność swojej placówki, a także szanowanego przez otoczenie.

Kolejną pozycją wskazaną przez respondentów jest Kod Leonarda da Vinci napisany przez Dana Browna ${ }^{32}$. Podczas rozwiązywania zagadki główni bohaterowie docierają do biblioteki Wydziału Teologii i Religioznawstwa King's College, gdzie wita ich uśmiechnięta i serdeczna Pamela Gettum - młoda bibliotekarka, która odbiega od stereotypu zarówno wyglądem, jak i charakterem. Nie jest formalistką, lecz osobą skłonną do pomocy oraz pełną serdeczności dla użytkowników, ma dystans do przepisów bibliotecznych oraz do samej siebie. Gdy główni bohaterowie przedstawiali jej swoje pytanie, wykazała zaangażowanie i ekscytację.

Ankietowani zapamiętali również bibliotekę stworzoną na kartach trzech powieści Cień wiatru ${ }^{33}$, Gra anioła ${ }^{34}$ oraz Więzień nieba ${ }^{35}$. Zbudowany przez Carlosa Ruiza Zafóna obraz biblioteki-cmentarza stanowi bardzo oryginalny przykład, świadczący o zmianach zachodzących w przedstawianiu bibliotek w utworach. Znacząco odbiega on od przyjętego stereotypu. Wprawdzie miejsce to jest rzadko odwiedzane i nieznane szerszej publiczności, a czas w nim wyraźnie stanął w miejscu, jednak równocześnie cechuje je wyjątkowa i jedyna w swoim rodzaju atmosfera, pełna tajemniczości i przyciągająca odbiorcę. Ponadto intryga ze śmiercią i tragiczną miłością w tle pozwala myśleć, że ludzi związanych z książką nie omijają przygody. Wizerunek ten jest niezwykle korzystny, pokazuje połączenie powszechnych wyobrażeń o bibliotekach z elementami, które skutecznie dementują pogłoski o wszechobecnej nudzie i nijakości tych miejsc. Zachęcają czytelnika do dołączenia do grona ,wybranych”, którzy mają szansę poznać tajemnicze labirynty regałów oraz kryjące się na nich biblioteczne skarby.

O bibliotece oraz bibliotekarzach pisze w swojej książce Kafka nad morzem jeden z najbardziej znanych japońskich pisarzy Haruki Murakami ${ }^{36}$. Główny bohater

\footnotetext{
32 D. Brown, Kod Leonarda da Vinci, Warszawa 2006.

33 C.R. Zafón, Cień wiatru, Warszawa 2008.

34 C.R. Zafón, Gra anioła, Warszawa 2011.

35 C.R. Zafón, Więzień nieba, Warszawa 2012.

36 H. Murakami, Kafka nad morzem, Warszawa 2007.
} 
od dziecka lubił spędzać czas w bibliotekach i uważa je za swój dom. Po licznych perypetiach dostaje pracę jako asystent bibliotekarza w jednej z nich, a z powodu problemów mieszkaniowych może w niej także zamieszkać. Sama praca w bibliotece przedstawiona została jako mało wymagająca. Do głównych zadań bibliotekarzy należy otwarcie oraz zamknięcie biblioteki. Sprzątaniem oraz wprowadzaniem pozycji do bazy danych zajmują się specjalnie zatrudnione do tego osoby. Do zadań asystenta bibliotekarza należy również pomoc czytelnikom w wyszukiwaniu konkretnych pozycji, czytelników jednak w bibliotece jest niewielu, więc w czasie pracy można spokojnie poczytać znajdujące się na półkach książki.

Dewey: wielki kot $w$ matym mieście ${ }^{37}$ to kolejna wskazana przez ankietowanych pozycja opisująca życie codzienne w bibliotece publicznej, znajdującej się w niewielkim amerykańskim miasteczku. W środku zimy do bibliotecznej wrzutni na książki trafił kociak. Szefowa biblioteki postanowiła się nim zaopiekować i dać mu schronienie w bibliotece. Książka pokazuje pracę w bibliotece, a także procesy, które są zazwyczaj niewidoczne dla użytkownika. Bibliotekarze przedstawieni są jako ludzie z własnymi problemami i marzeniami, którzy starają się jak najlepiej wykonywać swoją pracę i pomagać czytelnikom.

Ostatnią pozycją zapamiętaną przez czytelników jest powieść Umberto Eco Imię róży ${ }^{38}$. Główny bohater przyjeżdża do pewnego opactwa, by pomóc w wyjaśnieniu morderstwa. Z biegiem czasu dochodzi do kolejnych zbrodni. Okazuje się, że kluczem do rozwiązania zagadki jest klasztorna biblioteka. Opisana została przez autora jako miejsce tajemnicze i niebezpieczne, jej bogaty księgozbiór mieści się w pomieszczeniach przypominających labirynt, w którym bardzo łatwo jest zabłądzić. Jednocześnie życie mieszkańców klasztoru poświęcone jest pracy w bibliotece, do ich codziennych zajęć należy tłumaczenie manuskryptów oraz zdobienie ich wymyślnymi ilustracjami. Dostęp do biblioteki mają pracujący w niej mnisi, czasami za zgodą opata mogą z niej korzystać przyjeżdżający goście. Biblioteka w utworze pokazana jest jako miejsce skrywające tajemnice, jednocześnie budzące strach. Przedstawieni przez autora mnisi są osobami bogobojnymi, oddanymi swojej pracy w skryptorium, chroniącymi dostępu do biblioteki.

W zapamiętanych przez respondentów utworach biblioteki przedstawione są zazwyczaj jako miejsca dające dostęp do ogromnej wiedzy, która może być wykorzystana z pożytkiem przez osoby potrafiące z bibliotek korzystać. Dostęp do części z przedstawionych książnic jest ograniczony, niektóre z nich są dedykowane określonym grupom społecznym, w innych są wydzielone miejsca, z których korzystać mogą tylko osoby posiadające do tego specjalne upoważnienie. Są to zazwyczaj miejsca pełne tajemnic, budzące wśród użytkowników lęk i zarazem podziw. Zdecydowanie przeważa pozytywny wizerunek tych miejsc, czy to magicznych, czy zwyczajnych, zachęcający do odwiedzania bibliotek przez czytelników.

37 V. Myron, B. Witter, Dewey: wielki kot w małym mieście, Kraków 2008.

38 U. Eco, Imię róży, Warszawa 2011. 
Bibliotekarze $\mathrm{w}$ przedstawionych utworach zaprezentowani są $\mathrm{w}$ różnoraki sposób: od pomocnych i miłych dla czytelników, przez wywyższających się specjalistów, do osób bardzo niechętnych użytkownikom i ich przebywaniu w bibliotekach. Takie sposoby przedstawienia bibliotekarzy odzwierciedlają główne stereotypy dotyczące tego zawodu. W części książek został podkreślony szacunek dla osób pracujących w tym zawodzie, również upór bibliotekarzy w dążeniu do posiadania jak najbardziej kompletnego księgozbioru. W innych zaakcentowano ich profesjonalizm w podejściu do czytelników.

$\mathrm{Na}$ koniec ankiety zostawiono pytanie otwarte, w którym respondenci byli proszeni o wymienienie stereotypów dotyczących bibliotek lub bibliotekarzy. Pytanie to miało na celu porównanie doświadczeń osobistych ankietowanych oraz wyobrażenia bibliotekarzy funkcjonującego w społeczeństwie. Odpowiedzi wskazują, że użytkownicy bibliotek mają zdecydowanie pozytywne zdanie na temat samego zawodu oraz pracujących w nim osób, jednakże nie są im obce negatywne opinie krążące w społeczeństwie.

Na pytanie „Czy spotkali się Państwo ze stereotypami dotyczącymi bibliotek lub bibliotekarzy? Jeśli tak proszę wymienić, jakie to stereotypy” uzyskano następujące odpowiedzi:

— niemiły bibliotekarz,

- często starsza pani niezainteresowana czytelnikiem,

- osoby nudne,

- osoby nieprzyjazne,

— zajęty swoimi sprawami,

- zrezygnowany,

- cichy,

- spokojny,

- zaniedbana kobieta, w szarym swetrze, z okularami w grubych, niemodnych oprawkach, nieumiejąca posługiwać się komputerem,

- oczytany,

- mól książkowy,

— starsza pani w okularach,

- introwertyk,

— bibliotekarze są nudni i zrzędliwi,

— znający wszystkie pozycje na regałach,

— inteligentny,

- taka stara pani z okularami, którą denerwuje każdy dźwięk,

— nieuprzejmi, zapatrzeni w książki,

- złośliwi bibliotekarze,

— brak nowości wydawniczych,

— noszą okulary. 


\section{Wnioski}

Przeprowadzone badania miały na celu ustalenie, jak użytkownicy Biblioteki WFAIS postrzegają bibliotekarzy. Większość ankietowanych oceniła ich pozytywnie, przypisując bibliotekarzom takie cechy charakteru, jak: uprzejmy, miły, pomocny, cierpliwy i komunikatywny. Część osób uznała, że bibliotekarze są zajęci własnymi sprawami - wynika to ze wspomnianej wcześniej nieznajomości procesów bibliotecznych i wewnętrznego podziału pracy w bibliotece. Czytelnicy uważają, że praca w bibliotece polega na pomocy użytkownikom i jeśli bibliotekarz zajmuje się innymi zadaniami, uważają, iż zajmuje się on własnymi sprawami. Wiek respondentów miał wpływ tylko na część odpowiedzi i to w bardzo wybiórczy sposób. Dlatego też w tym badaniu nie udało mi się potwierdzić wstępnego założenia, że wiek ankietowanych, a co za tym idzie rok studiów, na którym się znajdują, ma wpływ na ich postrzeganie zawodu bibliotekarza. Obalona została też teza, że na postrzeganie bibliotekarzy przez czytelników Biblioteki WFAIS mają wpływ postawy pracujących w tej bibliotece osób. Czytelnicy mają dobre doświadczenia z bibliotekami - zarówno miejsce, jak i pracownicy kojarzą się im pozytywnie. Ankietowani wykazali się również znajomością bibliotekarzy oraz bibliotek utrwalonych na kartach różnego rodzaju powieści. Dzięki podanym przez nich tytułom można było ustalić, jaki wizerunek bibliotekarzy został zapamiętany przez czytelników. W wymienionych powieściach dominował wizerunek pozytywny, jednakże w książkach dla młodszych odbiorców bibliotekarze zostali przedstawieni jako osoby niechętne czytelnikom, budzące strach wśród uczniów, zdecydowanie niezachęcające do odwiedzania biblioteki. Kreowanie takiego wizerunku, zwłaszcza w literaturze młodzieżowej, z pewnością jest humorystyczne i budzi uśmiech na ustach czytelników, jednak równocześnie tworzy w ich świadomości negatywny i stereotypowy obraz bibliotekarzy. Niekiedy taki przekaz może wywołać uprzedzenie młodych ludzi do bibliotek i ich pracowników. Respondenci spotkali się również z negatywnymi stereotypami dotyczącymi bibliotek i bibliotekarzy utrwalonymi w świadomości społecznej. Wymieniono ponad dwadzieścia zasłyszanych opinii dotyczących bibliotekarzy, w których dominował opis ich cech charakteru; głównie podkreślano, że są to osoby nudne, niemiłe, ciche i zapatrzone w książki. Respondenci spotkali się również z opiniami na temat wyglądu bibliotekarzy; najczęściej wymieniane przez nich odpowiedzi to: zaniedbana, starsza pani w okularach. Przeprowadzone badania potwierdzają wspomnianą wcześniej zasadę, że aktywni użytkownicy bibliotek mają dobre opinie o bibliotekach oraz ich pracownikach, niekorzystne wyobrażenia dotyczące tego zawodu w świadomości społecznej utrwalane są zaś głównie przez osoby niekorzystające z bibliotek. 


\section{Bibliografia}

\section{Opracowania}

Encyklopedia PWN, http://encyklopedia.pwn.pl/haslo/3979617/stereotyp.html [dostęp: 16.02.2018]. Firlej-Buzon A., Jak wygląda bibliotekarka?, „Poradnik Bibliotekarza” 2003, nr 9, s. 3-6.

Folga A., Wizerunek bibliotekarza w opinii studentów I roku Uniwersytetu Pedagogicznego w Krakowie, „Annales Universitatis Paedagogicae Cracoviensis. Studia ad Bibliothecarum Scientiam Pertinentia" 2016, nr 14, s. 153-164.

Kmita G., Stereotyp bibliotekarza w społeczeństwie a problem identyfikacji zawodowej biblioteka$r z y$, ,Notes Biblioteczny” 2007, nr 2, s. 12-13.

Kneale R.A., You don't look like a librarian!, http://www.librarian-image.net/perc.html [dostęp: 16.02.2018].

Kołodziejska J., Polubić bibliotekarzy, „Notes Wydawniczy” 1996, nr 6, s. 36.

Kowalska B., Kotlarek D., Bibliotekarz a stereotypy, „Biuletyn EBIB” 2006, nr 10, http://www.ebib. p1/2006/80/a.php?kowalska_kotlarek [dostęp: 3.03.2018].

Kruszewski T., Wizerunek bibliotekarzy w opiniach ich następców, „Bibliotekarz” 2005, nr 10, s. $8-12$.

Kruszewski T., Wizerunek bibliotekarzy w opiniach ich następców po dekadzie — raport z badań, „Przegląd Biblioteczny” 85, 2016, z. 4, s. 545-556.

Macrae C.N., Stangor C., Hewstone M., Stereotypy i uprzedzenia: najnowsze ujęcie, Gdańskie Wydawnictwo Psychologiczne, Gdańsk 1999.

Od stereotypu do wykluczenia, red. A. Fidelus, Wydawnictwo Uniwersytetu Kardynała Stefana Wyszyńskiego, Warszawa 2014.

Sobocha-Stanuch J., Picheta P., Stereotypy bibliotekarzy, http://www.profuturo.agh.edu.pl [dostęp: 15.07.2013].

Stereotypy - walka z wiatrakami?, red. A. Bujakowska, J. Szadura, Wydawnictwo Uniwersytetu Marii Curie-Skłodowskiej, Lublin 2011.

Wojciechowski J., Stereotyp określa świadomość, „Przegląd Biblioteczny” 2006, nr 4, s. 429-444.

Wojciechowski J., W imadle stereotypów, „Bibliotekarz” 2004, nr 2, s. 3-6.

\section{Materiały źródłowe}

Brown D., Kod Leonarda da Vinci, Świat Książki, Warszawa 2006.

Eco U., Imię róży, wyd. 6 przejrz. i popr., Noir sur Blanc, Warszawa 2015.

King S., Cztery pory roku, wyd. 15, Wydawnictwo Albatros A. Kuryłowicz, Warszawa 2014.

Kosik R., Felix, Net i Nika oraz Gang Niewidzialnych Ludzi, Powergraph, Warszawa 2004.

Murakami H., Kafka nad morzem, Warszawskie Wydawnictwo Literackie Muza, Warszawa 2007.

Myron V., Witter B., Dewey: wielki kot w małym mieście, Wydawnictwo Znak, Kraków 2008.

Pilipiuk A., Wilcze leże, Fabryka Słów, Lublin 2017.

Pratchett T., Niewidoczni akademicy, Prószyński Media, Warszawa 2010.

Pratchett T., Straż! Straż!, Prószyński i S-ka, Warszawa 2005.

Pratchett T., Wiedźmikołaj, Prószyński i S-ka, Warszawa 2004.

Pratchett T., Zbrojni, Prószyński i S-ka, Warszawa 2002.

Rowling J.K., Harry Potter i czara ognia, wyd. popr., Media Rodzina, Poznań 2012.

Rowling J.K., Harry Potter i kamień filozoficzny, wyd. popr., Media Rodzina, Poznań 2000.

Rowling J.K., Harry Potter i Zakon Feniksa, Media Rodzina, Poznań 2004.

Sapkowski A., Czas pogardy, SuperNOWA, Warszawa 2011. 
Zafón C.R., Cień wiatru, wyd. 3, Warszawskie Wydawnictwo Literackie MUZA, Warszawa 2007.

Zafón C.R., Gra anioła, Warszawskie Wydawnictwo Literackie MUZA, Warszawa 2008.

Zafón C.R., Więzień nieba, Warszawskie Wydawnictwo Literackie Muza, Warszawa 2012.

\title{
Perception of the librarian's profession: Stereotypes and opinions of users of the Library of the Faculty of Physics, Astronomy and Applied Computer Science of the Jagiellonian University
}

\begin{abstract}
Summary
Stereotypes have been functioning in the social consciousness for many years and have become an interesting topic of scientific research. Stereotypes are universally accepted, positive or negative ideas about certain phenomena, professions, people and institutions. Usually they do not have much in common with reality but general opinions are very difficult to tone down and it is practically impossible to make them disappear completely. The article presents rules of creation of the stereotypes and conditions of their preservation. Then, the author discuses in more detail the specific stereotypes associated with libraries and librarians, and will explain the reasons of their formation. The article also presents the results of a survey carried out in November 2018 among the users of the Library of the Faculty of Physics, Astronomy and Applied Computer Science, Jagiellonian University. The main goal of the survey was to determine how students and faculty employees perceive librarians and if they know about the stereotypes of the profession. Furthermore, respondents were asked to indicate literary works in which the figure of a librarian or a library itself appear; the article contains a brief analysis of the indicated titles.
\end{abstract}

KEYWORDS: stereotypes, image of a library in books, image of librarian in books, library stereotype, librarian stereotype 